\title{
Two-mica andalusite-bearing granite with no primary muscovite: constraints on the origin of post-magmatic muscovite in two-mica granites
}

\author{
Jacek Puziewicz' , Anna Pietranik' \\ Institute of Geological Sciences, University of Wrocław pl. M. Borna 9, 50-204 Wroclaw, Poland
}

Record

Crystallisation of magmatic andalusite and post-magmatic muscovite in two-mica granite from the Gęsiniec Intrusion records low pressure of granite crystallisation ( $\sim 0.050 .15 \mathrm{GPa}$ ).

Abstract

The two-mica granite from Gęsiniec (Strzelin Granitic Massif, SW Poland) consists of quartz, K-feldspar, normally zoned plagioclase (30 $\pm 7 \%$ An), subordinate biotite and muscovite and magmatic andalusite. Andalusite crystallised before the outer parts of plagioclase grains were formed. Biotite has constant $\mathrm{Fe} /(\mathrm{Fe}+\mathrm{Mg})$ ratio of approximately 0.81 . Five textural types of muscovite occur in the granite: (1) muscovite replacing andalusite, (2) embayed interstitial muscovite, (3) muscovite forming aggregates with biotite, (4) muscovite accompanying biotite and chlorite in microfissures and (5) fine muscovite forming fringes at the contact between larger muscovite plates and K-feldspar. They are commonly associated with albite.

Crystallisation of muscovite started significantly below the granite solidus, mostly by the replacement of andalusite. Formation of muscovite continued during cooling of host rock. The growth of individual plates was initiated at different undercoolings and the plates whose crystallisation was frozen at different stages of growth occur. Those that were formed earlier are richer in titanium and iron relative to the later ones. As the rock contains no Ti and Fe saturating phases, the content of Ti and $\mathrm{Mg}$ in muscovite depends on their local availability. The homogeneous $\mathrm{Fe} /(\mathrm{Fe}+\mathrm{Mg})$ ratio of biotite indicates that it was re-equilibrated at the post-magmatic stage.

\section{Introduction}

Andalusite and muscovite belong to those minerals of peraluminous granites, whose presence may be used to infer about the P-T conditions of host rock crystallisation. The solidus of wet peraluminous granite (Holtz et al., 1992, Joyce and Voigt, 1994) enters the stability field of andalusite (Holdaway, 1971) in the narrow zone located between $\sim 0.5$ and $1.5 \mathrm{kbar}$, showing that the andalusite-bearing granites possibly crystallise in that pressure range. The stability curve of $2 \mathrm{M}_{1}$ muscovite (Chatterjee and Johannes, 1974) and water-saturated granite solidus (Tuttle and Bowen, 1958) cross at approximately 0.4 GPa in the P-T diagram, indicating that the muscovite granites crystallise under pressures exceeding $4 \mathrm{kbar}$, provided the muscovite is primary.

The simple relationships between the stability field of andalusite and granite solidus are complicated by boron and fluorine, which shift the location of granite solidus in the P-T diagram to lower temperatures (Manning, 1981, Chorlton and Martin 1978; Pichavant, 1981), enlarging the pressure range of andalusite crys-
Keywords

Two-mica granite, magmatic andalusite, post-magmatic muscovite, titanium.

Received: 25 October 2016 Accepted: 6 December 2016

tallisation in the magma and diminishing its potential use as the crystallisation pressure indicator. Moreover, the location of andalusite/sillimanite fields boundary remains controversial and many authors suggest it to lie between those determined by Holdaway (1971) and Richardson et al. (1969), which also increases the overlap between the andalusite stability field and granite magma supersolidus area (for detailed discussion, see Clarke et al. 2005). The use of muscovite as the minimal crystallisation pressure indicator for granitic magmas is also not straightforward. This is because the stability of natural muscovite may deviate significantly from that indicated by experimental data and because the microscopic determination of the 'primary' muscovite may be dubious (Zen, 1988). Miller et al. (1981) suggested that titanium content is relatively high in magmatic muscovite and may be a useful criterion for distinguishing between those of primary and secondary origin, but in the granites containing no titanium-saturating phase, this criterion is not useful (Puziewicz and Koepke, 1991). Muscovite and $\mathrm{Al}_{2} \mathrm{SiO}_{5}$ phases are related by reaction relationship (muscovite $+\mathrm{SiO}_{2}=$ sanidine $+\mathrm{Al}_{2} \mathrm{SiO}_{5}+\mathrm{H}_{2} \mathrm{O}$ ). Therefore, the 
coexistence of $\mathrm{Al}_{2} \mathrm{SiO}_{5}$ and muscovite is theoretically restricted to the reaction line in the P-T-diagram. In natural systems, however, the coexistence of magmatic andalusite and muscovite in the same magma batch is possible (Pichavant et al., 1988), which suggests that the reaction is continuous under certain conditions probably because of increasing substitution of fluorine for water in muscovite.

In this paper, we present an example of andalusite-bearing twomica granite that contains the secondary muscovite only. The relationships amongst textural varieties of secondary muscovite and their chemical characteristics allow the interpretation of the evolution of muscovite in a cooling granite. Our example comes from the Gęsiniec Intrusive (SW Poland).

\section{Geological setting}

The Gęsiniec Intrusion belongs to the Strzelin Massif, a group of small (most often a few hundreds of meters in diameter) Variscan granitic, granodioritic and tonalitic intrusions occurring in the northeastern part of the Fore-Sudetic Block (SW Poland; East Sudetes, Figure 1). The intermediate to felsic magmas in the Strzelin Massif intruded in three major pulses: (1) tonalitic at circa $325 \mathrm{Ma}$, (2) granodioritic at circa $305 \mathrm{Ma}$ and (3) tonalitic II/granitic at circa 295 Ma (Oberc-Dziedzic et al. 2010, Oberc-Dziedzic and Kryza 2012, Oberc-Dziedzic et al. 2013, Oberc-Dziedzic et al. 2015). The Gęsiniec Intrusion was emplaced during the third episode and is composed of quartz diorite/tonalite and granodiorite, which are cut by two-mica granite dyke (Pietranik and Waight, 2008; Pietranik and Koepke, 2009; Oberc-Dziedzic and Kryza, 2012). Ages of quartz diorite, tonalite and two mica granite is circa $295 \mathrm{Ma}$, showing that the intrusion was formed by chemically distinct magmas within the similar time span (Pietranik and Waight, 2008, Oberc-Dziedzic and Kryza, 2012, Pietranik 2013).

Two-mica granites are common in the Strzelin Massif and form two types: (1) small plutons and (2) dykes cutting metamorphic and igneous rocks (Oberc-Dziedzic et al. 2015). The plutons of Gromnik, Gębczyce and Górka Sobocka are characterised by less evolved chemical composition (e.g. lower $\mathrm{SiO}_{2}$ ) and higher $\varepsilon N d(-4.5$ to -4.9$)$ when compared to the dykes from Strzelin and Gęsiniec ( $\varepsilon N d$ from -5.4 to -5.9 , Oberc-Dziedzic et al. 2015). Also Gromnik and Górka Sobocka granites contain more abundant mica compared to Gębczyce and Gęsiniec granites. The two-mica granite in the Gęsiniec Intrusion forms a several meters thick vein cutting all other plutonic rocks of the Gęsiniec Intrusion (ObercDziedzic and Kryza 2012). Small two-mica granite veins of thickness ranging from several centimetres to 1-2 m occur as well. The magmatic zircon grains from the granite were dated at $295 \pm$ $5 \mathrm{Ma}$ by using U-Pb method (Oberc-Dziedzic and Kryza 2012). The granite also contains abundant inherited grains with the range of ages from $1.5 \mathrm{Ga}$ to $374 \mathrm{Ma}$, which partly corresponds to the age range observed in the surrounding Strzelin gneisses $(2.0 \mathrm{Ga}$

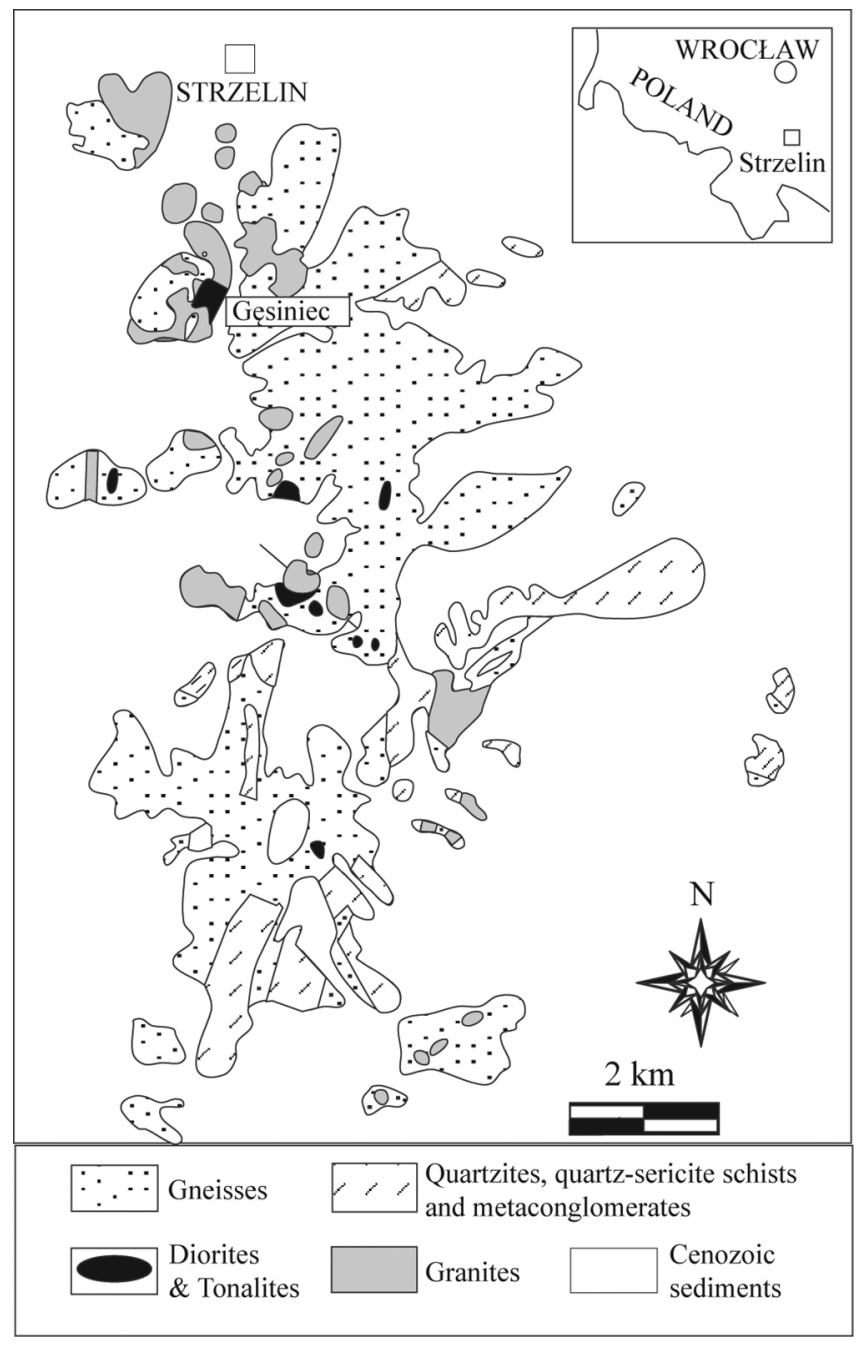

Figure 1. Geological sketch map of the Strzelin Crystalline Massif (after ObercDziedzic et al. 1996).

to $538 \mathrm{Ma}$, Oberc-Dziedzic et al. 2003). Also, higher $\varepsilon \mathrm{Nd}_{300}$ in the granites compared to gneisses suggests that the gneisses could not have been the only source of the granitic magma and the magmas were also derived from a more primitive source (ObercDziedzic et al. 2015). Generally, two-mica granites represent last stage of magmatism in the Strzelin Massif and require low temperatures of crystallisation and/or magma formation, re-melting of crustal source as well as involvement of highly differentiated magmas and fluids (Oberc-Dziedzic et al. 2015).

The occurrence of andalusite in granites of the Strzelin Massif was first reported by Bereś (1961) from the granite of Bialy Kościół. He described individual grains of andalusite occurring within the granite, similar to those described by us from the Gęsiniec twomica granite, and andalusite veins up to $15 \mathrm{~mm}$, attributing both of them to hydrothermal origin. 


\section{Analytical methods}

Chemical analyses of minerals were carried out at the laboratory of the Geology Department of the University of Warsaw (Poland) and at the laboratory of the Institute of Mineralogy, University of Hannover (Germany) on a CAMECA SX100 electron microprobe. Natural standards were used in both the laboratories. The detection limit for Ti, which is important for the discussed problem, was set at $250 \mathrm{ppm}$. The content of titanium in muscovite is presented in wt. $\%$ of $\mathrm{TiO}_{2}$ in diagram because of the resolution, which is better than that presented in atoms per formula unit. As $\mathrm{F}$ and Ba may also be important, their contents were analysed using $\mathrm{F}$-apatite and $\mathrm{BaSO}_{4}$ as the standards, and the beam diameter was enlarged to $2 \mu \mathrm{m}$. The detection limits were $1,000 \mathrm{ppm}$ for $\mathrm{Ba}$ and 800 ppm for F. However, because the analysed micas and feldspars do not contain significant amounts of fluorine and barium, those elements were not included in all of the analyses.

\section{Petrography and mineral chemistry}

The two-mica Gęsiniec granite samples analysed in this study consist of quartz, alkali feldspar, plagioclase, muscovite, biotite and scarce andalusite. Zircon and very rare monazite-(Ce) are accessories. Although other compositional varieties of two-mica granite were observed in the Gęsiniec Intrusion (Oberc-Dziedzic et al. 2015), we focus on the andalusite-bearing samples in order to understand the andalusite-muscovite relationship and its implication on P-T conditions of the granite crystallisation. In the studied rocks, andalusite occurs most often as anhedral, irregular or rounded grains within muscovite plates (Figure 2a). Very scarce alkali feldspar grains with quartz graphic intergrowths are present. The rock is serial, grains of plagioclase $(0.5-3 \mathrm{~mm})$ are subhedral to euhedral and grains of alkali feldspar $(0.5-3 \mathrm{~mm})$ and quartz (up to $5 \mathrm{~mm}$ ) are anhedral. Aggregates of biotite + muscovite or muscovite as well as individual plates of micas occur in interstices amongst quartz and feldspars. The rock is poor in Fe and $\mathrm{Mg}$ (Table 1). Andalusite-free two-mica granite variety occurs in small veins of the two-mica granite surrounding the main mass of the rock. It is characterised by the presence of small amounts of calcite in altered plagioclase grains.

Plagioclase is often zoned in a large scale; fine-scale oscillatory zonation occurs in some grains. Two types of grains are present: (1) normally zoned ones, some with strongly altered cores, and (2) very fine anhedral or subhedral grains associated with micas, often occurring within embayments of muscovite.

The normally zoned plagioclase grains are euhedral with slightly embayed, thin rims. Grains of large size (>1 mm) contain from $20-30 \%$ An in the cores through $11-16 \%$ in the inner mantles to $7-11 \%$ of $A n$ in the outer mantles (Table 2, analyses $1-6$ ). Decrease in anorthite is most often step-like at core-inner mantle boundary and gradual between inner and outer mantle. The
Table 1. Chemical analysis and CIPW norm of the two-mica granite from Gęsiniec.

\begin{tabular}{|c|c|}
\hline $\mathrm{SiO}_{2}$ & 74.74 \\
\hline $\mathrm{TiO}_{2}$ & 0.07 \\
\hline $\mathrm{Al}_{2} \mathrm{O}_{3}$ & 13.81 \\
\hline $\mathrm{Fe}_{2} \mathrm{O}_{3}$ & 0.68 \\
\hline $\mathrm{FeO}$ & 0.54 \\
\hline MnO & 0.02 \\
\hline MgO & 0.60 \\
\hline $\mathrm{CaO}$ & 0.65 \\
\hline $\mathrm{Na}_{2} \mathrm{O}$ & 3.98 \\
\hline $\mathrm{K}_{2} \mathrm{O}$ & 4.33 \\
\hline $\mathbf{P}_{2} \mathbf{O}_{5}$ & 0.05 \\
\hline Ioi & 0.44 \\
\hline Total & 99.91 \\
\hline $\mathbf{Q}$ & 32.91 \\
\hline or & 25.75 \\
\hline ab & 33.82 \\
\hline an & 2.92 \\
\hline C & 1.51 \\
\hline hy & 1.86 \\
\hline mt & 0.99 \\
\hline ilm & 0.13 \\
\hline ap & 0.11 \\
\hline
\end{tabular}

The analysis was done at the laboratory of the Institute of Geological Sciences, University of Wrocław.

outer parts of the inner mantles are in some grains slightly richer (2-3\%) in anorthite than the inner ones. Smaller normally zoned grains $(0.4-1 \mathrm{~mm})$ contain $10-14 \%$ of An in the cores and $8-12 \%$ in the mantles (Table 2, analyses 7-9), with abrupt decrease in anorthite content by $2-4 \%$ in the middle part of the mantle (Table 2 , analysis 10). The strongly altered plagioclase cores contain 1-4\% of An in the cores (Table 2, analyses 11 and 12). Abrupt decrease in An content occurs at mantle-embayed rim boundary in all grains. The An content in the rims is $2-3 \%$ (Table 2, analyses 13 and, 14). Small, rounded grains associated with micas are albitic (10-2\% An; Table 2, analyses 15-17). The anorthite content measured in this study is similar to that presented in Oberc-Dziedzic et al. (2015). 

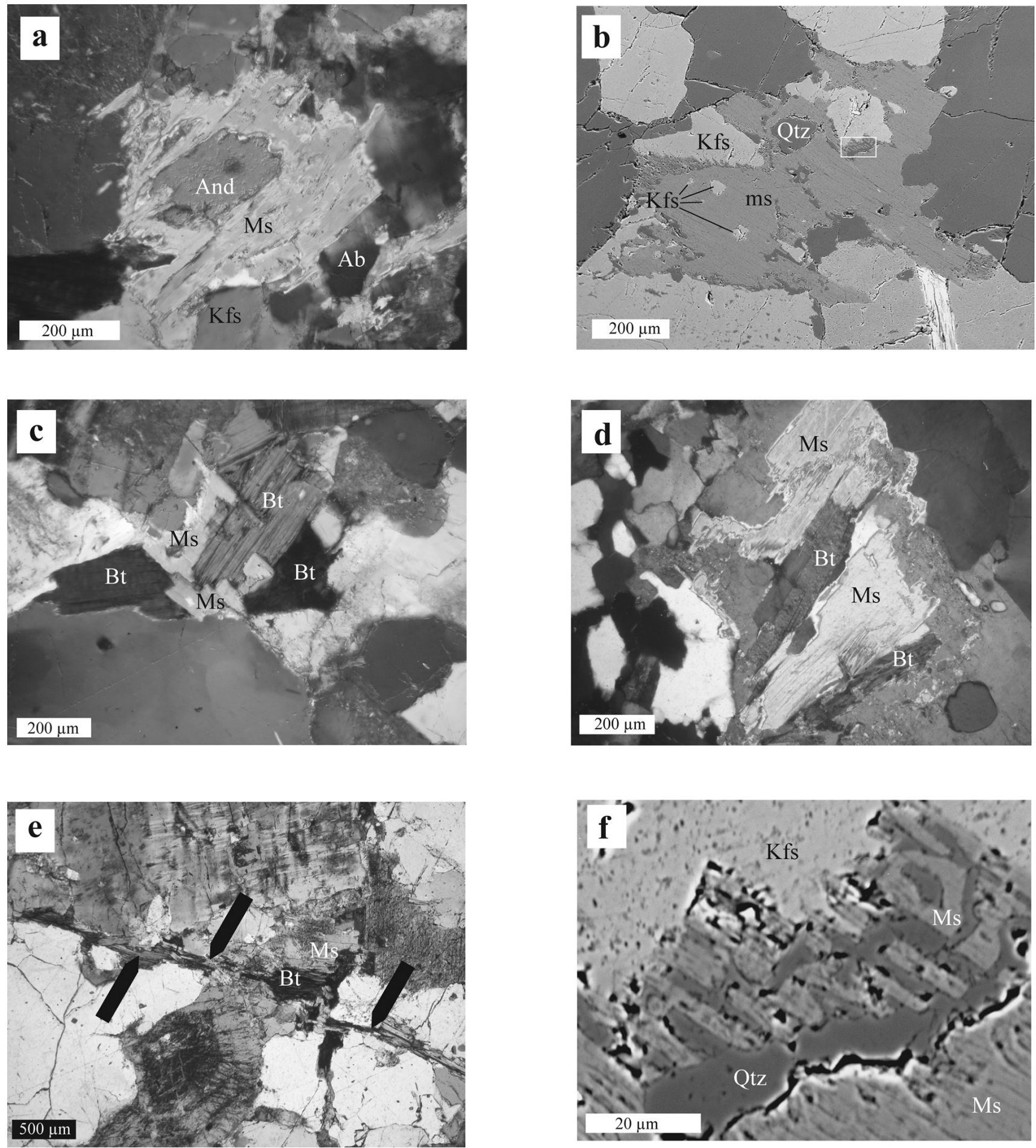

Figure 2. Muscovite forms in the Gęsiniec two-mica granite. (a) Anhedral muscovite with relic of andalusite (optical microscope image); (b) Embayed plate of muscovite with intergrowths of quartz and $K$-feldspar, rimmed by muscovite-quartz fringe at the contact with $K$-feldspar. White rectangle marks the area depicted in Figure 2f (BSE image); (c) Muscovite-biotite aggregate, muscovite texturally younger than biotite (optical microscope image); (d) Muscovite-biotite aggregate, biotite filling pull-apart in muscovite and thus texturally younger than muscovite (optical microscope image); (e) Muscovite-biotite filling of microfracture (indicated by the arrows, optical microscope image); ( $f$ ) Muscovite-quartz fringe at the margin of a plate depicted in Figure $2 b$ (BSE image). Mineral name abbreviations after Kretz (1983): Ms, muscovite; Bt, biotite; And, andalusite; Kfs, potassium feldspar; Ab, albite; Qtz, quartz. 
Table 2. Representative chemical analyses of plagioclase from the Gęsiniec two-mica granite

\begin{tabular}{c|c|c|c|c|c|c|c|c|c|c|c|c|c|c|c|c|c}
\hline & $\mathbf{1}$ & $\mathbf{2}$ & $\mathbf{3}$ & $\mathbf{4}$ & $\mathbf{5}$ & $\mathbf{6}$ & $\mathbf{7}$ & $\mathbf{8}$ & $\mathbf{9}$ & $\mathbf{1 0}$ & $\mathbf{1 1}$ & $\mathbf{1 2}$ & $\mathbf{1 3}$ & $\mathbf{1 4}$ & $\mathbf{1 5}$ & $\mathbf{1 6}$ & $\mathbf{1 7}$ \\
\hline & Core & Core & $\begin{array}{c}\text { Inner } \\
\text { mantle }\end{array}$ & $\begin{array}{c}\text { Inner } \\
\text { mantle }\end{array}$ & $\begin{array}{c}\text { Outer } \\
\text { mantle }\end{array}$ & $\begin{array}{c}\text { Outer } \\
\text { mantle }\end{array}$ & Core & Mantle & Mantle & Mantle & Core & Core & Rim & Rim & & & \\
\hline $\mathbf{S i O}_{\mathbf{2}}$ & 62.28 & 63.38 & 64.83 & 65.48 & 65.91 & 66.36 & 65.03 & 65.83 & 65.84 & 67.50 & 68.76 & 69.34 & 66.86 & 68.29 & 67.73 & 67.74 & 65.69 \\
\hline $\mathbf{A l}_{\mathbf{2}} \mathbf{O}_{\mathbf{3}}$ & 23.99 & 23.73 & 22.46 & 21.56 & 21.45 & 21.41 & 22.05 & 21.31 & 21.62 & 20.87 & 19.64 & 19.27 & 21.23 & 20.09 & 21.12 & 19.89 & 21.21 \\
\hline $\mathbf{C a O}$ & 5.34 & 4.20 & 3.12 & 2.72 & 2.16 & 1.74 & 2.47 & 1.72 & 2.24 & 0.95 & 0.21 & 0.34 & 1.53 & 0.29 & 0.97 & 0.48 & 2.04 \\
\hline $\mathbf{N a}_{\mathbf{2}} \mathbf{O}$ & 8.54 & 8.91 & 9.69 & 10.18 & 10.23 & 10.63 & 9.89 & 10.51 & 10.11 & 10.84 & 11.5 & 10.82 & 10.85 & 11.10 & 11.05 & 10.89 & 10.27 \\
\hline $\mathbf{K}_{\mathbf{2}} \mathbf{O}$ & 0.15 & 0.41 & 0.44 & 0.18 & 0.19 & 0.19 & 0.42 & 0.19 & 0.36 & 0.02 & 0.14 & 0.05 & 0.17 & 0.14 & 0.19 & 0.13 & 0.15 \\
\hline $\mathbf{T o t a l}$ & 100.30 & 100.63 & 100.54 & 100.12 & 99.94 & 100.33 & 99.86 & 99.56 & 100.17 & 100.18 & 100.25 & 99.82 & 100.64 & 99.91 & 101.06 & 99.13 & 99.36 \\
\hline $\mathbf{O r}$ & 1 & 2 & 2 & 1 & 1 & 1 & 2 & 1 & 2 & 0 & 1 & 0 & 1 & 1 & 1 & 1 & 1 \\
\hline $\mathbf{A b}$ & 74 & 78 & 83 & 86 & 89 & 91 & 86 & 91 & 87 & 95 & 98 & 98 & 97 & 98 & 94 & 97 & 89 \\
\hline $\mathbf{A n}$ & 25 & 20 & 15 & 13 & 10 & 8 & 12 & 8 & 11 & 5 & 1 & 2 & 2 & 1 & 5 & 2 & 10 \\
\hline
\end{tabular}

1-6- normally zoned, large plagioclase grain

7-10- normally zoned, small plagioclase grain

11 and 12 - strongly altered cores

13 and 14 - thin, embayed rims of normally zoned grains

15 - small (about $150 \mu \mathrm{m}$ ) grain located at the margin of muscovite, which contains andalusite relic

16 and 17 - small (about 30 and $100 \mu \mathrm{m}$, respectively) grains of anorthite-poor plagioclase in embayments of muscovite plates

Table 3. Representative chemical analyses and structural formulae $\left(\mathrm{O}^{2-}=22\right)$ of muscovite from the Gęsiniec two-mica granite.

\begin{tabular}{|c|c|c|c|c|c|c|c|c|c|c|c|c|c|c|c|c|c|}
\hline & 1 & 2 & 3 & 4 & 5 & 6 & 7 & 8 & 9 & 10 & 11 & 12 & 13 & 14 & 15 & 16 & 17 \\
\hline $\mathrm{SiO}_{2}$ & 46.88 & 46.51 & 47.36 & 46.09 & 46.17 & 47.53 & 46.62 & 47.17 & 46.03 & 45.84 & 46.07 & 45.94 & 46.17 & 46.76 & 46.62 & 47.82 & 45.80 \\
\hline $\mathrm{TiO}_{2}$ & 0.02 & 0.14 & 0.01 & 0.00 & 0.20 & 0.14 & 0.19 & 0.02 & 0.02 & 0.49 & 0.26 & 0.26 & 0.78 & 0.02 & 0.02 & 0.21 & 1.02 \\
\hline $\mathrm{Al}_{2} \mathrm{O}_{3}$ & 38.82 & 38.43 & 37.67 & 38.22 & 36.47 & 37.69 & 38.04 & 37.07 & 36.72 & 36.85 & 37.28 & 37.10 & 36.97 & 36.85 & 36.34 & 33.33 & 33.74 \\
\hline $\mathrm{FeO}^{\mathrm{a})}$ & 0.82 & 1.27 & 0.92 & 0.75 & 1.19 & 1.32 & 1.41 & 1.66 & 1.34 & 1.52 & 1.30 & 1.23 & 1.58 & 1.14 & 1.08 & 3.04 & 3.39 \\
\hline MnO & 0.05 & 0.07 & 0.01 & 0.05 & 0.00 & 0.03 & 0.00 & 0.00 & 0.06 & 0.00 & 0.03 & 0.05 & 0.00 & 0.00 & 0.00 & 0.07 & 0.01 \\
\hline MgO & 0.16 & 0.30 & 0.19 & 0.09 & 0.32 & 0.32 & 0.33 & 0.61 & 0.25 & 0.29 & 0.28 & 0.31 & 0.31 & 0.32 & 0.31 & 1.11 & 0.82 \\
\hline $\mathrm{Na}_{2} \mathrm{O}$ & 0.34 & 0.40 & 0.42 & 0.41 & 0.49 & 0.37 & 0.59 & 0.24 & 0.52 & 0.37 & 0.51 & 0.48 & 0.50 & 0.31 & 0.34 & 0.19 & 0.31 \\
\hline $\mathrm{K}_{2} \mathrm{O}$ & 8.77 & 9.34 & 9.52 & 10.65 & 10.29 & 7.93 & 9.97 & 9.38 & 10.34 & 11.03 & 9.65 & 10.87 & 11.04 & 10.38 & 10.29 & 10.04 & 10.47 \\
\hline Total & 95.86 & 96.46 & 96.10 & 96.26 & 95.13 & 95.33 & 97.15 & 96.15 & 95.28 & 96.39 & 95.38 & 96.24 & 97.35 & 95.78 & 95.00 & 95.81 & 95.56 \\
\hline Si & 6.09 & 6.05 & 6.17 & 6.04 & 6.13 & 6.19 & 6.06 & 6.16 & 6.11 & 6.05 & 6.08 & 6.06 & 6.04 & 6.16 & 6.19 & 6.34 & 6.15 \\
\hline $\mathbf{T i}$ & 0.00 & 0.01 & 0.00 & 0.00 & 0.02 & 0.01 & 0.02 & 0.00 & 0.00 & 0.05 & 0.03 & 0.03 & 0.08 & 0.00 & 0.00 & 0.02 & 0.10 \\
\hline Al(IV) & 1.91 & 1.95 & 1.83 & 1.96 & 1.87 & 1.81 & 1.94 & 1.84 & 1.89 & 1.95 & 1.92 & 1.94 & 1.96 & 1.84 & 1.81 & 1.66 & 1.85 \\
\hline Al(VI) & 4.04 & 3.94 & 3.95 & 3.95 & 3.84 & 3.98 & 3.88 & 3.87 & 3.86 & 3.78 & 3.88 & 3.83 & 3.74 & 3.88 & 3.87 & 3.56 & 3.48 \\
\hline $\mathrm{Fe}$ & 0.09 & 0.14 & 0.10 & 0.08 & 0.13 & 0.14 & 0.15 & 0.18 & 0.15 & 0.17 & 0.14 & 0.14 & 0.17 & 0.13 & 0.12 & 0.34 & 0.38 \\
\hline Mn & 0.00 & 0.01 & 0.00 & 0.01 & 0.00 & 0.00 & 0.00 & 0.00 & 0.01 & 0.00 & 0.00 & 0.01 & 0.00 & 0.00 & 0.00 & 0.01 & 0.00 \\
\hline $\mathbf{M g}$ & 0.03 & 0.06 & 0.04 & 0.02 & 0.06 & 0.06 & 0.06 & 0.12 & 0.05 & 0.06 & 0.06 & 0.06 & 0.06 & 0.06 & 0.06 & 0.22 & 0.16 \\
\hline $\mathrm{Na}$ & 0.12 & 0.10 & 0.11 & 0.12 & 0.13 & 0.09 & 0.15 & 0.06 & 0.13 & 0.09 & 0.13 & 0.12 & 0.13 & 0.08 & 0.09 & 0.05 & 0.08 \\
\hline $\mathbf{K}$ & 1.45 & 1.55 & 1.58 & 1.74 & 1.74 & 1.32 & 1.65 & 1.56 & 1.75 & 1.86 & 1.63 & 1.83 & 1.84 & 1.74 & 1.74 & 1.70 & 1.79 \\
\hline $\mathrm{fm}$ & 0.738 & 0.707 & 0.733 & 0.818 & 0.679 & 0.642 & 0.706 & 0.604 & 0.751 & 0.747 & 0.722 & 0.692 & 0.738 & 0.663 & 0.664 & 0.607 & 0.700 \\
\hline
\end{tabular}

a) Total iron as $\mathrm{FeO}$

1 and 2 -inner and outer parts, respectively, of muscovite plate containing andalusite relics (cf. Figure 2b);

3 and 4 - muscovite plates occurring in inner and outer parts, respectively, of partial pseudomorph after andalusite;

5 - embayed plate occurring in the muscovite aggregate;

6-8 - core (6) and margins (7 and 8) of embayed muscovite;

9 - low-titanium muscovite plate in the aggregate;

10 - high-titanium muscovite plate overgrown with biotite;

11 - high-titanium muscovite plate in biotite/chlorite-muscovite aggregate

12 and 13 - muscovite plates from biotite and/or chlorite dominated microfissure fillings

14 and 15 - small plates forming the fringe on the margin of a larger plate;

16 and 17 - intergrowths in plagioclase. 

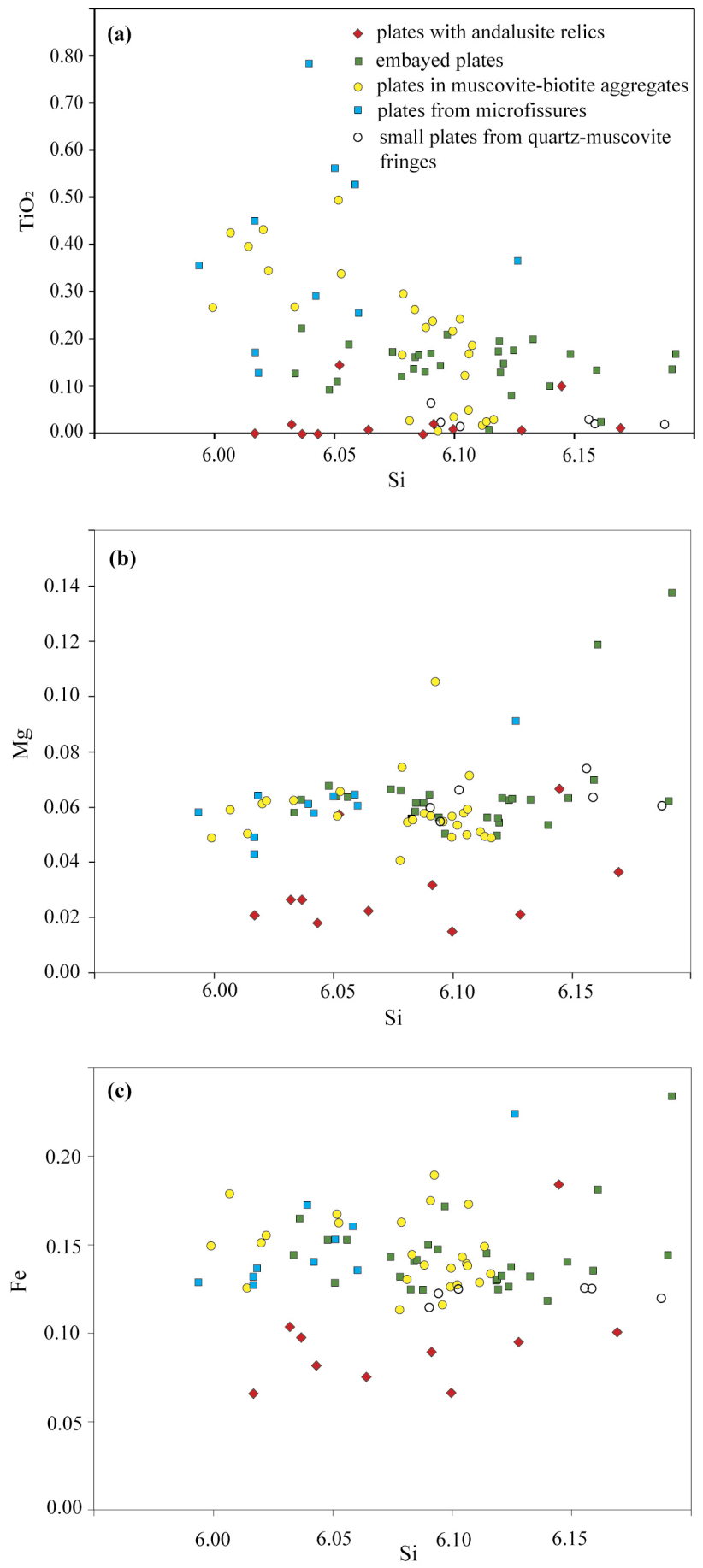

Figure 3. Points representing muscovites from the Gęsiniec two-mica granite on the diagrams: (a) $\mathrm{TiO}_{2}$ (wt.\%) versus Si (atoms per formula unit, a pfu), (b) Mg versus Si (a pfu) and (c) Fe versus Si (a pfu).

Alkali feldspar occurs as anhedral grains that are commonly cross-hatched twinned. Scarce untwinned grains are perthitic. $\mathrm{Ba}$ content in plagioclase and K-feldspar is below the detection limit of 0.1 wt. $\%$.

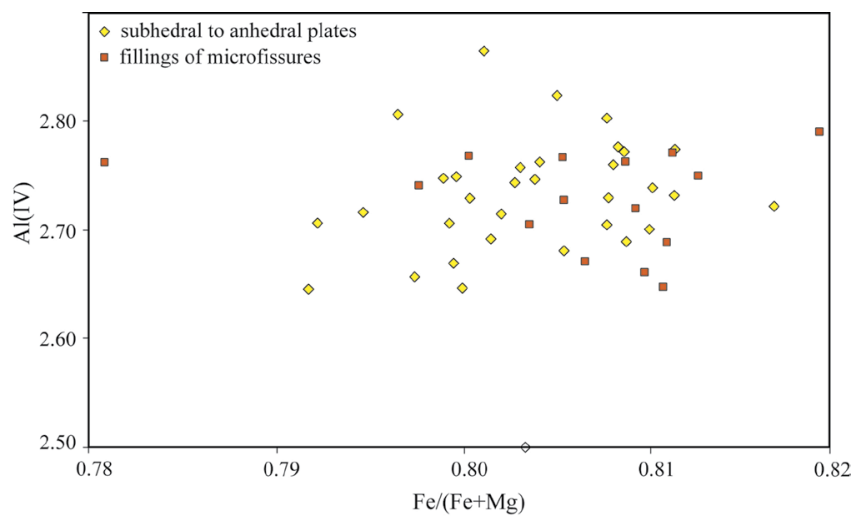

Figure 4. Points representing biotites from the Gęsiniec two-mica granite on the diagram $\mathrm{Al}(\mathrm{IV})$ versus $\mathrm{Fe} /(\mathrm{Fe}+\mathrm{Mg})$.

Quartz forms anhedral grains occurring in interstices amongst feldspars or scarce fine rounded grains within feldspars. Some grains of quartz contain rounded plates of muscovite.

The size and shape of muscovite plates are variable. Muscovite forms:

1. anhedral plates occurring within plagioclase or in interstices, commonly containing small irregular grains of andalusite (Figure 2a). They are practically free of $\mathrm{TiO}_{2}\left(0.03 \mathrm{wt} . \% \mathrm{TiO}_{2}\right.$; Figure 3a; Table 3, analysis 1$)$. Very rare domains containing up to 0.14 wt.\% $\mathrm{TiO}_{2}$ (Table 3, analysis 2) are located at the margins of this kind of plates. This group also comprises small, shred aggregates of plates, occurring in partial pseudomorphs after andalusite (Table 3, analyses 3 and 4). Albitic plagioclase (5\% of anorthite) occurs in their closest neighbourhood (Table 2, analysis 15). The andalusite occurring in that of muscovite is of S2 or S3 textural type of Clarke et al. (2005);

2. embayed plates of up to $1 \mathrm{~mm}$ in size occurring in interstices individually and in biotite (or chlorite) - muscovite or muscovite aggregates (Figure 2b). They are often associated with small plagioclase grains (10-2\% of An; Table 2, analyses 16 and 17) occurring within embayments and contain small Kfeldspar intergrowths. The plates of this kind contain most often $0.10-0.22$ wt.\% of $\mathrm{TiO}_{2}$ (Figure 3a; Table 3, analyses 5-7). Sporadically, at the margins of plates, their titanium content is comparable to that of post-andalusite muscovite (Table 3, analysis 8);

3. fine anhedral plates occurring in biotite and/or chlorite - muscovite aggregates. The relationships between muscovite and biotite suggest that muscovite is younger than biotite (Figure 2c) or the opposite (Figure 2d). The muscovite $\mathrm{TiO}_{2}$ content is strongly variable (Figure $3 \mathrm{a}$ ). Some of the plates contain very little $\mathrm{TiO}_{2}$ (<0.04 wt. \%; Table 3, analysis 9), whereas others contain amounts of $\mathrm{TiO}_{2}$ reaching up to $0.49 \mathrm{wt}$. \% (Table 3 , analyses 10,11$)$. The content of titanium is not related to the position of the plate relative to other members of the aggre- 
Table 4. Representative chemical analyses and structural formulae $\left(\mathrm{O}^{2-}=22\right)$ of biotite and chlorite $\left(\mathrm{O}^{2-}=28\right)$ from the Gęsiniec two-mica granite.

\begin{tabular}{|c|c|c|c|c|c|c|c|c|c|}
\hline & 1 & 2 & 3 & 4 & 5 & 6 & 7 & 8 & 9 \\
\hline $\mathrm{SiO}_{2}$ & 31.99 & 33.01 & 33.48 & 32.71 & 32.92 & 33.90 & 33.08 & 23.18 & 23.59 \\
\hline $\mathrm{TiO}_{2}$ & 2.10 & 2.55 & 2.60 & 1.90 & 2.29 & 3.09 & 2.02 & 0.06 & 0.24 \\
\hline $\mathrm{Al}_{2} \mathrm{O}_{3}$ & 19.01 & 19.05 & 19.50 & 19.36 & 19.62 & 19.55 & 19.52 & 21.80 & 20.29 \\
\hline $\mathrm{FeO}^{\mathrm{a})}$ & 29.04 & 27.41 & 26.62 & 27.92 & 26.50 & 25.25 & 27.61 & 38.25 & 36.85 \\
\hline Mno & 0.68 & 0.97 & 0.77 & 0.49 & 0.63 & 0.77 & 0.65 & 0.94 & 1.14 \\
\hline MgO & 4.05 & 3.65 & 3.74 & 3.64 & 3.53 & 3.40 & 3.67 & 5.01 & 5.47 \\
\hline $\mathrm{Na}_{2} \mathrm{O}$ & 0.03 & 0.04 & 0.06 & 0.02 & 0.08 & 0.02 & 0.04 & 0.01 & 0.01 \\
\hline $\mathrm{K}_{2} \mathrm{O}$ & 8.42 & 9.79 & 10.01 & 9.40 & 9.75 & 9.55 & 9.59 & 0.01 & 0.03 \\
\hline Total & 95.32 & 96.47 & 96.78 & 95.44 & 95.32 & 95.53 & 96.18 & 89.26 & 87.62 \\
\hline Si & 5.14 & 5.22 & 5.25 & 5.23 & 5.24 & 5.33 & 5.24 & 5.41 & 5.28 \\
\hline $\mathrm{Ti}$ & 0.25 & 0.30 & 0.31 & 0.23 & 0.27 & 0.37 & 0.24 & - & - \\
\hline Al & 3.60 & 3.55 & 3.60 & 3.64 & 3.68 & 3.62 & 3.64 & 5.75 & 5.67 \\
\hline Al(IV) & 2.86 & 2.78 & 2.75 & 2.77 & 2.76 & 2.67 & 2.76 & 2.59 & 2.33 \\
\hline Al(VI) & 0.73 & 0.78 & 0.86 & 0.87 & 0.92 & 0.95 & 0.88 & 3.16 & 3,34 \\
\hline $\mathrm{Fe}$ & 3.90 & 3.63 & 3.49 & 3.73 & 3.53 & 3.32 & 3.66 & 7.16 & 6.89 \\
\hline$M n$ & 0.09 & 0.13 & 0.10 & 0.07 & 0.08 & 0.10 & 0.09 & 0.18 & 0.22 \\
\hline $\mathbf{M g}$ & 0.97 & 0.86 & 0.87 & 0.87 & 0.84 & 0.80 & 0.87 & 1.67 & 1.82 \\
\hline $\mathrm{Na}$ & 0.01 & 0.01 & 0.02 & 0.01 & 0.02 & 0.01 & 0.01 & - & - \\
\hline K & 1.72 & 1.98 & 2.00 & 1.92 & 1.98 & 1.91 & 1.94 & - & - \\
\hline fm & 0.80 & 0.81 & 0.80 & 0.81 & 0.81 & 0.81 & 0.81 & $19^{\mathrm{b})}$ & $20^{\text {b) }}$ \\
\hline
\end{tabular}

a) Total iron as $\mathrm{FeO}^{b)} \mathrm{Mg}$-chlorite mol \%

$\mathrm{Ti}, \mathrm{Na}$ and $\mathrm{K}$ not included in chlorite formula calculation

1-3-outer parts of a plate occurring in biotite-muscovite aggregate, no zircon inclusions

4 - plate from the biotite aggregate, no zircon inclusions

5 - individual plate rich in zircon intergrowths

6 and 7 - elongated plate in the microfissure, no zircon inclusions

8 - chloritized part of an individual biotite plate

9 - small plate in the biotite-muscovite aggregate filling microfissure

gate. However, the plates associated with post-biotitic chlorite usually have elevated contents of titanium;

4. fine plates occurring in elongated microfissure fillings dominated by biotite and/or chlorite (Figure 2e, see also biotite description). The $\mathrm{TiO}_{2}$ content is highly variable but usually relatively high (up to about $0.8 \mathrm{wt} . \%$; Figure $3 \mathrm{a}$; Table 3 , analyses 12 and 13);

5. fine fringe aggregates located at the margins of larger muscovite plates. SEM large magnification BSE images show them to consist of fine intergrowths of muscovite and quartz (Figure 2f). They contain $<0.03$ wt. \% of $\mathrm{TiO}_{2}$ (Figure 3a; Table 3 , analyses 14 and 15 ).
Very fine plates of muscovite occur within plagioclase; sometimes they are oriented according to the crystallographic directions of the host. Their $\mathrm{TiO}_{2}$ content is above $0.10 \mathrm{wt} . \%$ and strongly varies from plate to plate (0.11-1.02 wt.\%, Table 3, analyses 16 and 17). The fine plates replacing plagioclase are characterised by noticeable higher contents of silica, magnesium and iron relative to other varieties of muscovite occurring in the described two-mica granite. This kind of muscovite will not be discussed further in this study because of their obvious secondary origin.

$\mathrm{Mg}$ and Fe contents are lowest in muscovite replacing andalusite (Figure 3b, c). Muscovite occurring in fringes is significantly richer in both elements (Figure 3b, c). The amounts of fluorine and bari- 

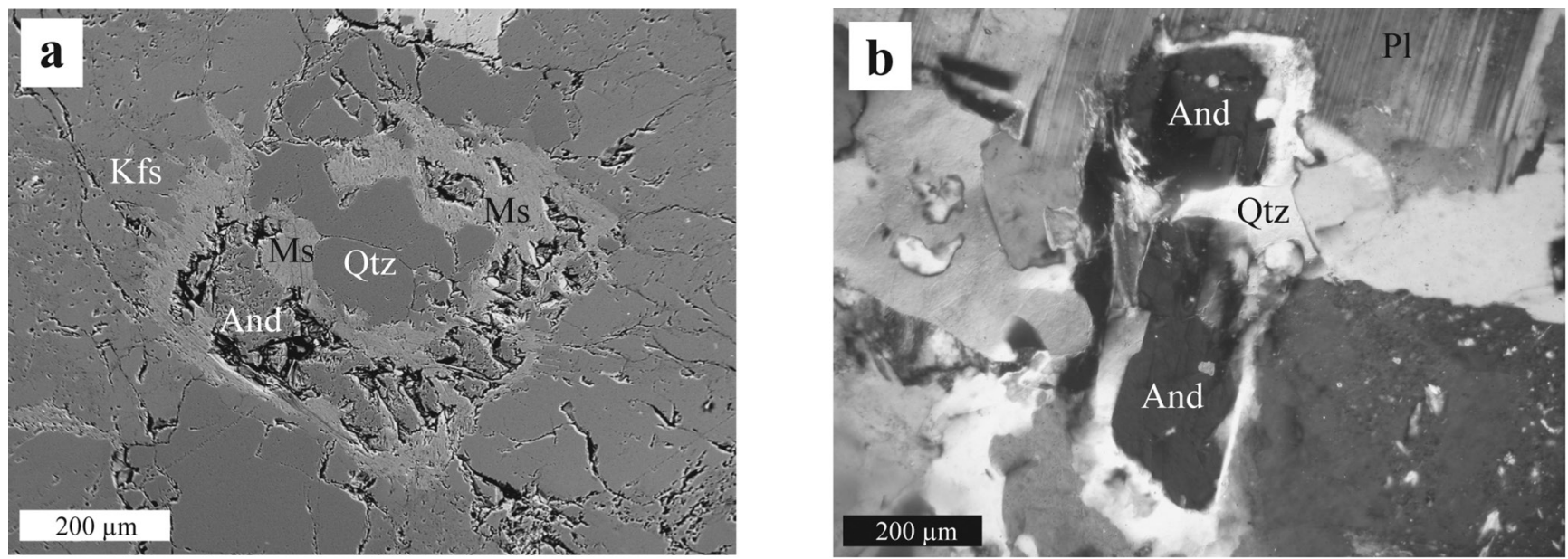

Figure 5. Andalusite in the Gęsiniec two-mica granite. (a) Partial pseudomorph after andalusite, preserving original euhedral shape of the grain (BSE image). (b) Subhedral andalusite crystal, older than the neighbouring plagioclase grain (optical microscope image). For mineral name abbreviations, see Figure 2.

um in the studied muscovites in the samples containing relics of andalusite are low $(\mathrm{F}<0.14$ wt. \%, Ba below the detection limit of $0.1 \mathrm{wt} . \%)$. The muscovite occurring in andalusite-free granite forming small veins is richer in $\mathrm{F}$ and $\mathrm{Ba}(\mathrm{F}=0.11-0.31 \mathrm{wt} . \%, \mathrm{BaO}=0.11-$ 0.28 wt.\%).

Biotite is brown and often discoloured to a different degree. Its $\mathrm{Fe} /(\mathrm{Fe}+\mathrm{Mg})$ ratio is practically constant (0.79-0.82; Figure 4$)$ in all analysed plates. The Al content is high (2.65-2.85 atoms pfu; Figure 4) and typical for peraluminous biotite-muscovite and aluminium silicate biotite-muscovite granites (Speer, 1984). Many of the analyses yield results intermediate between those of biotite and chlorite, indicating that the plates of biotitic appearance are composed of fine-scale intergrowths of both the minerals. Biotite forms:

1. subhedral to anhedral plates, some containing zircon inclusions. They occur in interstices individually or in aggregates with muscovite. Their $\mathrm{TiO}_{2}$ content varies from 1.90 to 2.60 wt.\% (Table 4, analyses 1-5). The differences in $\mathrm{TiO}_{2}$ content within an individual plate are up to $0.5 \mathrm{wt} . \%$ (Table 4 , analyses 1 and 2);

2. fine, subhedral to anhedral plates forming thin, elongated aggregates with smaller amounts of muscovite and chlorite, marking extensional microfissures in a granite (Figure 2e) and typically containing no zircon intergrowths. The relationships between biotite and muscovite are variable, within the same aggregate pull-aparts in muscovite filled by biotite as well as those in biotite filled by muscovite occur. The content of $\mathrm{TiO}_{2}$ is relatively variable (2.2-3.09 wt.\%;, Table 4, analyses 6 and 7).

Andalusite forms anhedral, irregular or rounded grains within muscovite plates. Partial pseudomorphs after andalusite, including quartz and muscovite (Figure 5a), are scarce. Very rare are interstitial subhedral andalusite grains of size reaching $0.5 \mathrm{~mm}$, free of muscovite or surrounded by thin muscovite rim. Outer parts of plagioclase grains are anhedral relative to them (Figure 5b). Andalusite contains between 0.6 and 1.1 wt.\% of $\mathrm{Fe}_{2} \mathrm{O}_{3}$.

Chlorite is Fe rich (17-20\% of clinochlore in the Association Internationale pour l'Etude des Argiles (AIPEA) classification scheme of Bailey, 1980; Table 4, analyses 8 and 9).

\section{Discussion}

\subsection{Sequence of crystallization}

The presented relationships amongst the mineral grains forming the two-mica granite suggest that plagioclase crystallised first from the magma and later it was joined by potassium feldspar, andalusite and quartz. Oberc-Dziedzic et al. (2015) describe the pinite-bearing two-mica granite from Gęsiniec with pinite being the first crystallizing phase; however, the pinite was not observed in the samples analysed in this study. Another difference is the titanium content in muscovite, which is below $0.03-0.60 \mathrm{wt} . \% \mathrm{TiO}_{2}$ in Oberc-Dziedzic et al. (2015) and up to $1.0 \mathrm{wt} . \%$ in the samples analysed in this study. Also biotite composition is different in the samples $\mathrm{Fe} /(\mathrm{Fe}+\mathrm{Mg})=0.73-0.75$ in Oberc-Dziedzic et al. (2015) compared to $\mathrm{Fe} /(\mathrm{Fe}+\mathrm{Mg})=0.8$ in this study. Therefore, despite similarities in mineral and chemical composition, we suggest that the sample described in this study is different from the two-mica granite described by Oberc-Dziedzic et al. (2015), probably because of local variations in composition. However, the andalusitemuscovite occurrence in the samples described by us makes them potentially important for understanding the relationships between two phases in two-mica granites in general.

The zoning pattern of plagioclase is indicative of crystallisation in a cooling environment, probably with abrupt change in crystallisation conditions at the core/mantle boundary, disturbance during 
outer mantle crystallisation and post-magmatic rimming by albite. Some of the plagioclase grains were subjected to post-magmatic alteration by replacing their cores by albite. This, plus local presence of the quartz-feldspar graphic intergrowths, suggests high water activity at the advanced stages of magma crystallisation and its relative abundance at the post-magmatic stage. Andalusite crystallised during the formation of plagioclase mantles (cf. Figure $5 b$ ). Micas are late in the crystallisation sequence. The two-mica granite occurring in small veins contains plagioclase with fine grains of calcite, contains no andalusite and is characterised by slightly increased contents of fluorine and barium in muscovite and feldspars. This suggests that the rock was subjected to more intense post-magmatic alteration, which supposedly enabled complete replacement of andalusite by muscovite.

The location of andalusite relative to plagioclase and other minerals suggests magmatic origin of the former. No indications of concomitant crystallisation of andalusite and muscovite are present. The relationships of the granite solidus, andalusite stability field and stability limit of muscovite in the P-T diagram (Figure 6) exclude the possibility of primary muscovite crystallisation, and in our opinion, this is the case in the Gęsiniec two-mica granite. As no boron minerals occur in the granite and the micas contain practically no fluorine, the presence of magmatic andalusite is possible because of the decrease in solidus temperature induced by aluminium saturation (Holtz et al.,1992, Joyce \& Voigt, 1994) or because of the shift of andalusite-sillimanite boundary to the temperatures higher than those indicated in the Holdaway diagram (Clarke et al. 2005). Thus, the presence of andalusite indicates low $(\sim 0.05-0.15 \mathrm{GPa})$ crystallisation pressure of the host rock (Figure 6). Muscovite must have started to crystallise at temperatures much below the solidus under this pressure (cf. Figure 6). The location of biotite relative to the other grains suggests it to be of late magmatic origin. However, the biotite plates filling pull-aparts in muscovite must be of post-magmatic origin. The same refers to biotite occurring in microfissures in the granite (cf. Figure 2e). As the $\mathrm{Fe} /(\mathrm{Fe}+\mathrm{Mg}$ ) ratio of biotite is homogeneous throughout the rock (approximately 0.8 ), we infer that the mineral re-equilibrated its iron and magnesium ratio at the post-magmatic stage.

\subsection{Muscovite}

We distinguished five textural types of muscovite: (1) post-andalusitic, (2) large embayed, (3) fine in aggregates with biotite, (4) fine in microfissures and (5) fringe-like growing at the margins of large embayed one.

The plates of muscovite occurring in fringes are overgrown with quartz, which suggests that they are the product of the reaction K-feldspar $+\mathrm{Al}_{2} \mathrm{SiO}_{5}+\mathrm{H}_{2} \mathrm{O}=$ muscovite $+\mathrm{SiO}_{2}$, in which aluminium silicate components were transported to the reaction place. Muscovite replacing andalusite is also associated with quartz and was formed by the same reaction, but here potas-

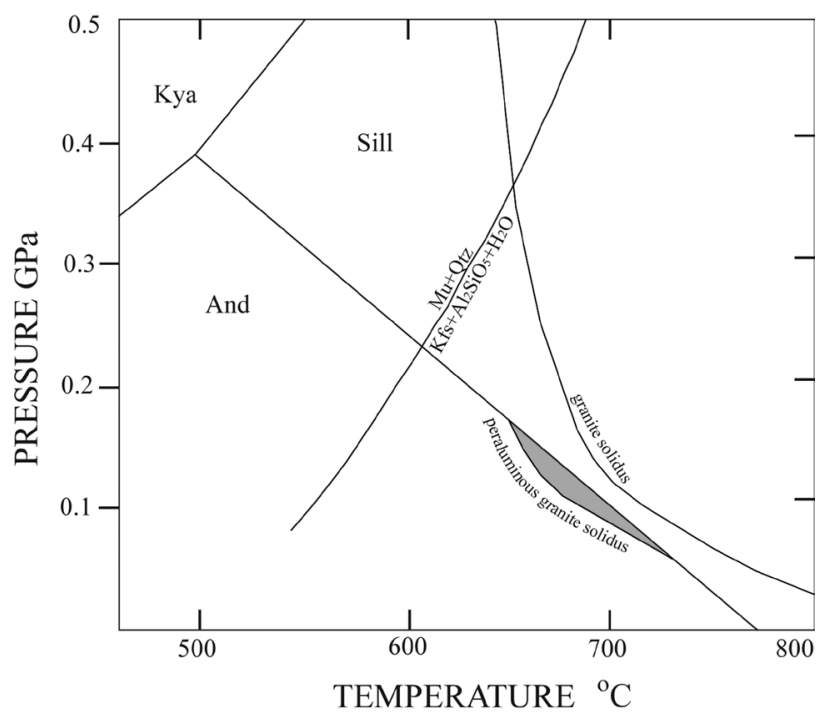

Figure 6. Locations of granite solidus (Tuttle, Bowen 1958) and peraluminous granite solidus (Joyce, Voigt 1994) relative to the stability fields of aluminium silicates (Holdaway 1971) and muscovite + quartz stability curve (Chatterjee, Johannes 1974) in the P-T diagram.

sium feldspar components must have been transported to the reaction place.

The muscovite occurring in fringes and that replacing andalusite are practically titanium free (Figure 3a). The magnesium and iron contents of post-andalusitic muscovite are significantly lower than those of fringe muscovite. In our opinion, this may be attributed to different mechanisms of the muscovite-forming reaction. The occurrence of Ti-free domains at the margins of some larger plates suggests that fringes are replaced by a plate because of the dissolution of quartz and dissolution/recrystallisation of muscovite, leading to the growth of a plate. However, most of the plates are significantly richer in titanium $\left(0.10-0.30 \mathrm{wt} . \%\right.$ of $\left.\mathrm{TiO}_{2}\right)$. Those parts of the plates originated under higher titanium activity, thus at the different (probably earlier) stage of rock evolution.

Muscovite replacing andalusite occurs as aggregates of fine, variously oriented plates at small degrees of replacement (i.e. much andalusite, little muscovite in the replaced grain). At high degrees (i.e. little andalusite, much muscovite), muscovite occurs as a single large plate. The next step in the replacement process is supposedly represented by large embayed interstitial plates of form similar to those containing andalusite relics. This textural change is correlated with increasing titanium, iron and magnesium contents (Figure 3). The muscovite replacing andalusite is often associated with albitic plagioclase, which shows its low-temperature origin (i.e. that of the albite stability field in the P-T diagram). Various amounts of titanium, iron and magnesium in post-andalusitic muscovite and various textures of muscovite show that the replacement was frozen at different stages. The andalusite-muscovite reaction was probably initiated at various temperatures in 
different places in the cooling rock, depending on local conditions. Thus, it advanced to the different degree before the reaction ceased because of the decrease in temperature. The textural relationships andalusite/muscovite are identical to some of those presented by Clarke et al (2005) in their Figure 7, but we attribute them to entirely post-magmatic processes. The muscovite plates occurring in aggregates with biotite and/or chlorite contain highly variable amounts of titanium, magnesium and iron (cf. Figure 3). The plates of the highest titanium content occur in association with biotite and/or chlorite. As the Gęsiniec two-mica granite contains no magnesium- and iron-saturating phases, the contents of theose two elements in muscovite are supposedly governed by their local availability. However, the magnesium content is similar in most of the muscovite plates (cf. Figure 3b), which suggests the values close to the equilibrium ones.

All muscovite types have $\mathrm{TiO}_{2}$ contents below $0.6 \mathrm{wt} . \%$, the value suggested by Zen (1988) to be the lower limit of magmatic muscovite. As no Ti mineral occurs in the two-mica granite, all the muscovite crystallised in a titanium-unsaturated conditions. The titanium amount is thus governed by local availability of titanium. This is exemplified by enlarged Ti contents in plates associated with post-biotitic chlorite, to which all Ti bounded in the biotite was available after its chloritisation. These amounts of titanium mark probably the saturation limit of muscovite during chlorite crystallisation at the post-magmatic stage. As almost all of the analysed plates contain less titanium, temperature was not the main factor affecting its content in muscovite. Therefore, the $\mathrm{TiO}_{2}$ content of muscovite cannot be an argument for its origin in the described two-mica granite (Puziewicz and Koepke 1991). However, it is a valuable indicator of stages of muscovite crystallisation.

\section{Conclusions}

The two-mica granite from the Gęsiniec Intrusion in the Strzelin Granitic Massif is poor in ferromagnesian components and contains magmatic andalusite, which crystallised before the outer parts of the plagioclase were formed. This indicates the low pressure of granite crystallisation ( 0.05-0.15 GPa). Muscovite occur- ring in the granite is highly variable texturally and crystallised at the post-magmatic stage under temperatures much below solidus under conditions corresponding to those of greenschist facies metamorphism. Muscovite was formed because of the reaction K-feldspar $+\mathrm{Al}_{2} \mathrm{SiO}_{5}+\mathrm{H}_{2} \mathrm{O}=$ muscovite $+\mathrm{SiO}_{2^{\prime}}$ in which the reactants occurred partly in solution. The first step in muscovite formation is crystallisation of fine plates overgrown with quartz. Their dissolution/recrystallisation produces well-formed, homogeneous plates. Various forms of muscovite are observable in the described rock, suggesting that the mineral crystallisation was initiated at various temperatures during the cooling of the rock. Thus, both initial and advanced steps of muscovite crystallisation are frozen in the granite.

The muscovites are crystallised under Ti-undersaturated conditions, and their titanium content was determined by local availability of this element. Therefore, the Ti content of the described muscovites cannot be a criterion for their origin. However, the data presented in this study show that titanium content variation maybe useful for distinguishing the stages of post-magmatic muscovite crystallisation. The post-andalusitic and fringe muscovite are those whose process of formation was not commenced. This is supposedly due to the decrease in temperature in a cooling rock. Both of them are low in titanium and magnesium. The other kinds of muscovite are supposedly older and contain higher amounts of titanium and magnesium.

Our study shows that the $\mathrm{Fe} /(\mathrm{Fe}+\mathrm{Mg}$ ) ratio of biotite occurring in the granitic rocks maybe re-equilibrated at the post-magmatic stage, even if mineral form and presence of zircon intergrowths suggest its primary origin. The example described in this study shows that in some high-level granites, andalusite may be the primary peraluminous phase, which is replaced by muscovite at the post-magmatic stage. Thus, the high-level two-mica granites whose solidus was not significantly lowered by fluorine and boron contain supposedly no primary muscovite.

\section{Acknowledgements.}

This study was financed from the research funds for the Institute of Geological Sciences, University of Wrocław.

\section{References}

[1] Bailey S.W. 1980. Summary and recommendation of AIPEA nomenclature committee on clay minerals. Amer. Miner., 65: 1-7.

[2] Chatterjee N., Johannes W. 1974. Thermal stability and standard thermodynamic properties of synthetic $2 \mathrm{M}_{1}$ muscovite $\mathrm{KAl}_{2}\left[\mathrm{~A} 1 \mathrm{Si}_{3} \mathrm{O}_{10}(\mathrm{OH})_{2}\right]$. Contrib. Miner. Petrol., 48: 89-114.

[3] Bereś B. 1961. On the occurrence of andalusite in the granite of the Strzelin Massif. Zesz. Nauk. U. Wr., B6: 155-166.

[4] Chorlton L.B., Martin R.F. 1978. The effect of boron on the granite solidus. Can. Mineral., 16: 239-244.
[5] Clarke D.B., Dorais M., Barbarin B., Barker D., Cesare B., Clarke A., El Baghdadi M., Erdmann S., Förster H.-J., Gaeta M., Gottesmann B., Jamieson R.A., Kontak D.J., Koller F., Gomes C.L., London D., Morgan VI G.B., Neves L.J.P.F., Pattison D.R.M., Pereira A.J.S.C. Pichavant M., Rapela C.W., Renno A.D., Richards S., Roberts M., Rottura A., Saavedra J., Sial A.N., Toselli A.J., Ugidos J.M., Uher P., Villaseca C., Visona D., Whitney D.L., Williamson B., Woodard H.H. 2005. Occurrence and origin of andalusite in peraluminous felsic igneous rocks. J. Petrol., 46: 441-472. 
[6] Holdaway M.J. 1971. Stability of andalusite in the aluminum silicate phase diagram. Am. J. Sci., 271: 97-131.

[7] Holtz F., Johannes W., Pichavant M. 1992. Effect of excess aluminium on phase relations in the system Qz-Ab-Or: experimental investigation at 2 kbar and reduced $\mathrm{H}_{2} \mathrm{O}$ activity. Eur. J. Mineral., 4: 137-152.

[8] Joyce D.B., Voigt D.E. 1994. A phase equilibrium study in the system $\mathrm{KAISi}_{3} \mathrm{O}_{8}-\mathrm{NaAlSi}_{3} \mathrm{O}_{8}-\mathrm{SiO}_{2}-\mathrm{Al}_{2} \mathrm{SiO}_{5}-\mathrm{H}_{2} \mathrm{O}$ and petrogenetic implications. Am. Mineral., 79: 504-512.

[9] Kretz R. 1983. Symbols for rock-forming minerals. Am. Mineral., 68: 277-279.

[10] Manning D.A.C. 1981. The effect of fluorine on liquidus phase relationships in the system Qz-Ab-Or with excess water at $1 \mathrm{~kb}$. Contrib. Miner. Petrol., 76: 206-215.

[11] Miller C.F., Stoddard E.F., Bradfish L.J., Dollase W.A. 1981. Composition of plutonic muscovite: genetic implications. Can. Mineral., 19: 25-34.

[12] Oberc-Dziedzic T., Pin C., Duthou J.L., Couturie, J.P. (1996): Age and origin of the Strzelin granitoids (Fore-Sudetic Block, Poland): ${ }^{87} \mathrm{Rb} /{ }^{86} \mathrm{Sr}$ data Neues Jahrb. Miner. Abh., 171: 187-198.

[13] Oberc-Dziedzic, T., Kryza, R., 2012. Late stage Variscan magmatism in the Strzelin Massif (SW Poland): SHRIMP zircon ages of tonalite and Bt-Ms granite of the Gęsiniec intrusion. Geological Quarterly, 56 (2): 225-236.

[14] Oberc-Dziedzic, T., Kryza, R., Białek, J., 2010. Variscan multi stage granitoid magmatism in Brunovistulicum: petrological and SHRIMP $\mathrm{U} / \mathrm{Pb}$ zircon geochronological evidence from the southern part of the Strzelin Massif, SW Poland. Geological Quarterly, 54 (3): 301-324.

[15] Oberc-Dziedzic, T., Kryza, R., Pin, C., Madej, S., 2013. Variscan granitoid plutonism in the Strzelin Massie (SW Poland): petrology and age of the composite Strzelin intrusion. Geological Quarterly, 57 (2): 269-288.

[16] Oberc-Dziedzic, T., Kryza, R., Pin, C., 2015. Last stage of Variscan granitoid magmatism in the Strzelin Massif (SW Poland): petrology and age of biotite granite. Geological Quarterly, 59 (4): 718-737.

[17] Oberc-Dziedzic, T., Kryza, R., Klimas, K., Fanning, M.C., 2003. SHRIMP $\mathrm{U} / \mathrm{Pb}$ zircon geochronology of the Strzelin gneiss, SW Poland: evi- dence for a Neoproterozoic thermal event in the Fore-Sudetic Block, Central European Variscides. Int. J. Earth Sci., 92: 701-711.

[18] Pichavant M. 1981. An experimental study of the effect of boron on a water-saturated haplogranite at $1 \mathrm{kbar}$ vapour pressure. Contrib. Miner. Petrol., 76: 430-439.

[19] Pichavant M., Kontak D.J., Herrera J.V., Clark A.H. 1988. The MiocenePliocene Macusani Volcanics, SE Peru. 1. Mineralogy and magmatic evolution of a two-mica aluminosilicate-bearing ignimbrite suite. Contrib. Mineral. Petrol., 100: 300-324.

[20] Pietranik A., 2013, Dating zircon from the Gęsiniec Intrusion by LAICPMS (Laser Ablation - Inductively Coupled Plasma Mass Spectrometry). Geoscience Notes 1, 63-67.

[21] Pietranik A., Koepke J., 2009. Interactions between dioritic and granodioritic magmas in mingling zones: plagioclase record of mixing, mingling and subsolidus interactions in the Gęsiniec Intrusion, NE Bohemian Massif, SW Poland. Contr. Miner. Petr., 158: 17-36.

[22] Pietranik A., Waight T., 2008. Processes and sources during Late Variscan dioritic-tonalitic magmatism: insights from plagioclase chemistry (Gęsiniec Intrusion, NE Bohemian Massif, Poland). J. Petrol., 49: 1619-1645.

[23] Puziewicz J., Koepke, J. 1991. Controls on $\mathrm{TiO}_{2}$ content in muscovite and biotite from a two-mica granite, the Strzegom Sobótka Massif, Sudetes, SW Poland. Neues Jahrb. Miner., Monatsh., 1991: 253-261.

[24] Richardson S.W., Gilbert M.C., Bell P.M. 1969. Experimental determination of kyanite-andalusite and andalusite-sillimanite equilibria; the aluminum silicate triple point. Amer. Jour. Sci. 267: 259-272.

[25] Speer J.A. 1984. Micas in igneous rocks. Rev. Mineral.,13: 299-356.

[26] Tuttle O.F., Bowen, N.L. 1958. Origin of granite in the light of experimental studies in the system $\mathrm{NaAlSi}_{3} \mathrm{O}_{8}-\mathrm{KAISi}_{3} \mathrm{O}_{8}-\mathrm{SiO}_{2}-\mathrm{H}_{2} \mathrm{O}$. Geolog. Soc. Am. Mem., 74: 1-153.

[27] Zen, E-An 1988. Phase relations of peraluminous granitic rocks and their petrogenetic implications. Ann. Rev. Earth Planet. Sci., 1988: 21-51. 